\title{
Bioremediation of Acetochlor in Soil and Water Systems by Cyanobacterial Mat
}

\author{
Yasser El-Nahhal, ${ }^{1,2}$, Yousef Awad ${ }^{3}$, Jamal Safi ${ }^{2,3}$ \\ ${ }^{1}$ The Islamic University, Gaza, Palestine \\ ${ }^{2}$ Environmental Protection and Research Institute (EPRI), Palestinian National Authority (PNA), Gaza, Palestine \\ ${ }^{3}$ Al-Azhar University, Gaza, Palestine \\ Email: y_el_nahhal@hotmail.com;eprigaza@palnet.com
}

Received April 26, 2013; revised May 29, 2013; accepted June 27, 2013

Copyright (C) 2013 Yasser El-Nahhal et al. This is an open access article distributed under the Creative Commons Attribution License, which permits unrestricted use, distribution, and reproduction in any medium, provided the original work is properly cited.

\begin{abstract}
This study investigated the bioremediation of organic pollution in soil and water systems by cyanobacterial mats collected from Wadi Gaza. Acetochlor, a model compound of herbicide, was used as a standard organic pollutant. Various concentrations of acetochlor were injected in soil and water samples pre-treated with cyanobacterial mat for several periods of time. Percentage of growth of wheat as a test plant was taken as indicator of bioremediation of acetochlor. Results showed that acetochlor was degraded in both soil and water systems. Degradation was much faster in the water system than in the soil system. Concentrations of acetochlor above the field rate did not affect the bioremediation process in the water system whereas it did in soil pots. Furthermore, bioremediation in water system was nearly completed in 15 days whereas it did not reach high percentage in the soil system. These encouraging results are new contribution in field of bioremediation of pesticide by cyanobacterial mats and suggest that application of cyanobacterial mat could be a fast and suitable methodology for bioremediation of organic pollutant in the ecosystem.
\end{abstract}

Keywords: Cyanobacterial Mat; Acetochlor; Soil and Water Systems

\section{Introduction}

Acetochlor is a widely used herbicide in the Middle East and world wide. Its frequent application has created environmental problems to the soil, the water and the eco-system. For instance acetochlor has been shown to be directly affecting the agro-ecosystem by impacting some biological functions such as the decomposition of soil organic matter and the availability of soil nutrients [1], and being toxic to humans and other mammals [2] and reducing the abundance and diversity of non-target organisms [3]. Acetochlor is classified as a leachable compound in the soil and its potential for contamination of the ground water is comparable with those of alachlor and metolachlor [4]. Acetochlor was detected in the rain samples collected from 4 sites in Iowa and other nine states in USA [5], in the streams and surface water [6] and in the groundwater [7]. Furthermore, the leaching behavior of acetochlor was carefully studied using columns techniques and determined that acetochlor has the potential of moving along the soil profile $[8,9]$. However, leaching of acetochlor was also restricted in the soil profile by the use of organo-clay formulations
$[8,10]$. Konda and Pasztoe [11], investigated the environmental behavior of acetochlor and reported that the maximum detected residues of acetochlor in the stream water was 1 order of magnitude higher than the maximum residue limit specified by the European Union (EU) for environmental and drinking water $(0.1 \mathrm{mg} / \mathrm{l})$.

Furthermore, several chloroacetanilides have been shown to cause health hazards, for instance, acetochlor can produce significant incidences of thyroid, bone, granular stomach and nasal cavity tumors in rats, and of liver and lung tumors in mouse [12]. It may also have induced glutathione-dependent cytotoxicity in cultured animal and human cells [13]. The mutagenicity of acetochlor, alachlor, butachlor, and metolachlor has been reviewed thoroughly [14]. Acetochlor was classified as likely to be carcinogenic to humans [15]. The objectives of this study are to investigate the bioremediation of acetochlor contamination in the soil and water systems and to optimize the bioremediation process. Our idea behind this work based on the use of cyanobacterial mats that were collected from Wadi Gaza, since the Wadi was exposed to different chemical pollution sources as we observed. Furthermore, our previous work in the use of cyanobacterial 
mats in the bioremediation studies [16-19] showed that the cyanobacterial mats were able to degrade diesel oil and hydrocarbons.

\section{Materials and Methods}

Analytical grade acetochlor, purity 98\% was purchased from ChemService USA. Its solubility limit in the water is $223 \mathrm{mg} \cdot \mathrm{L}^{-1},\left(25^{\circ} \mathrm{C}\right)$, stable for over 2 years at $20^{\circ} \mathrm{C}$. It is a hydrophobic herbicide with an octanol/water partitioning coefficient $\mathrm{K}_{\mathrm{ow}}=2.85$ [20].

\subsection{Soil Collection and Analysis}

Soil samples, were collected from the top $0-30 \mathrm{~cm}$ of the agricultural land located in Al Zawaida village in the middle governorate of Gaza strip, have no history of acetochlor application in the past 10 years. Soil samples were analyzed for physicochemical properties following the procedure described by El-Nahhal et al. [21].

\subsubsection{Determination of $\mathbf{p H}, \mathrm{EC}$ and Cations}

Ten g soil sample was transferred to $100 \mathrm{ml}$ plastic bottle, $50 \mathrm{ml}$ of distilled water was added to each flask and shaking overnight. After $24 \mathrm{~h} \mathrm{pH}$ and EC values were measured by digital and portable $\mathrm{pH}$ (handylab2, $\mathrm{pH}$ 320/Set-2, Best.-Nr 100 739, made in Germany) and conductivity meter (LF 318/Set, Best.-Nr 300 231, made in Germany). The soil suspensions were filtrated using normal Whatman filter paper. The filtrates were collected in plastic bottles and re-filtrated again to ensure ultra pure solution. Sodom, Potassium and Calcium ions were determined using atomic absorption apparatus.

\subsubsection{Determination of Available Phosphorus}

Ten $g$ of the tested soil samples were transferred to a 250 $\mathrm{ml}$ plastic bottle. About $200 \mathrm{ml}$ CAL-liquid (Calcium lactate + calcium acetate) was added to each tube and shaked for $2 \mathrm{~h}$ using rotary shaker. The samples were filtered 2 times as mentioned above. The filtrates were transferred to Atomic Absorption Apparatus for determination of Phosphorus.

\subsubsection{Determination of Total Nitrogen}

Selected representative soil samples were transferred to the laboratory of CNSHO analyzer, Euro EA 3000 Elemental Analyzer to determine $\mathrm{N}$ content in selected soil samples. In this laboratory few $\mathrm{mg}$ of dry soil were weighed and transferred to the CNSHO analyzer, for analysis.

\subsection{Collection of Cyanobacterial Mat Cells}

The floating blue green cyanobacterial mats used in these researches were collected from the western part of Wadi Gaza near the Mediterranean Sea beach by using algal net, and different volumes of plastic bottles. The collected mat was then submerged in a plastic bottle full with aqueous media from the same place [16-19].

The water temperature during the sampling process ranged between $24^{\circ} \mathrm{C}-31^{\circ} \mathrm{C}$; salinity ranged between $3 \%$ $3.6 \%$ and the $\mathrm{pH}$ ranged between 8.5 - 9.01. Each sampling process included a plastic bottle filled with green aqueous media from the surrounding of the mats as a growth media. The samples were then transferred to the laboratory and physically sieved using a $0.2 \mathrm{~mm}$ mesh sieve and then diluted with a ratio of $1: 1$ by tab water free from chlorine or any disinfecting agents and shacked very well to form homogenized suspension. The diluted samples were then incubated at $20^{\circ} \mathrm{C}-25^{\circ} \mathrm{C}$ in the laboratory [22]. The collection of cyanobacterial mats was repeated several times as required.

To assure the presence of cyanobacterial mats in the samples the population growth of mats in the solution were measured by recording the optical density of the solution using spectrophotometer at wave length $680 \mathrm{~nm}$ [23]. Furthermore, identification of cyanobacterial mat cultures in genera and specie used in this work is currently under our investigation.

\subsection{Soil Sterilization}

The collected soil samples were sieved using a $2 \mathrm{~mm}$ mesh size then sterilized using an autoclave (SS-325Automatic High-Pressure-Steam sterilizer Class I-B). In this technique, $6 \mathrm{~kg}$ soil was added to polyethylene packets and saturated with water and transported to smaller nylon envelops that are tolerant to high temperature. The soil samples were then kept in the autoclave under $120^{\circ} \mathrm{C}$ for 1.5 hours. Then the soil samples were left for cooling. The cooled soil was transferred to black plastic pots having 4 holes in the bottom, for the execution of the experiment.

\subsection{Acetochlor Solution Preparation}

Technical amount of acetochlor $\left(200 \mathrm{mg} \cdot \mathrm{L}^{-1}\right)$ was dissolved in $1 \mathrm{~L}$ of distilled water and used as a stock solution throughout the experiments to prepare the standard solution and the needed dilutions as planned in the experiments. The following concentrations of acetochlor were prepared and tested $0.0,0.055,0.11,0.22,0.44$, and $0.88 \mathrm{mg} \cdot \mathrm{Kg}^{-1}$ soil.

\subsection{Bioassay Technique}

The idea behind using bioassay technique is to evaluate the remaining concentration of acetochlor and thus to estimate the biodegradation in the soil and the aquatic media. The idea is based on the fact that bioassay technique is more sensitive than chemical technique, beside the fact that it can determine low concentrations and it is 
environmentally friendly as previously reported [24]. Based in the method previously reported [10,25], the herbicidal activity was determined according to Equation (1) (see below). Then the remaining concentration of acetochlor in soil was determined using Equation (2) which is initiated from a linear dose-response relationship from the above mentioned concentrations (Figure 1). Based on regression analysis, the necessary equation to evaluate the remaining concentration at the corresponding value of growth inhibition was determined. In these experiments, wheat (Triticum $s p$ ) was used as test plants for bioassay techniques [21].

In this procedure, appropriate concentrations as mentioned above were prepared and mixed thoroughly in the soil. Then the soil was distributed evenly to 5 plastic pots. Ten seeds of the test plant were sown in each pot. The pots were then carefully transferred to the growth chamber for 2 weeks and irrigated as necessary with regular water free from chlorine. After 2 weeks, the plant height was taken as indicator of growth and used to calculate $\%$ growth inhibition according to Equation (1).

$$
\text { \%Growth Inhibition }=100 \times\left(P_{c}-P_{t}\right) / P_{c}
$$

where $P_{c}$ and $P_{t}$ are the shoot heights of the control and the treated samples at any pot.

Furthermore, plotting \% Growth Inhibition versus concentrations and converting the relation to a log scale produced a liner relationship represented by Equation (2)

$$
Y=112.77 X .
$$

where $Y$ and $X$ represent \%Growth inhibition and concentration in log scal.

\subsection{Biodegradation of Acetochlor}

\subsubsection{Biodegradation in Soil Pots}

Twenty $\mathrm{ml}$ of cyanobacterial mats suspension were mixed with $340 \mathrm{gm}$ soil pots and left for 20 days before the cultivation and application of acetochlor herbicide. Acetochlor concentrations $(0.0,0.055,0.11,0.22,0.44$,

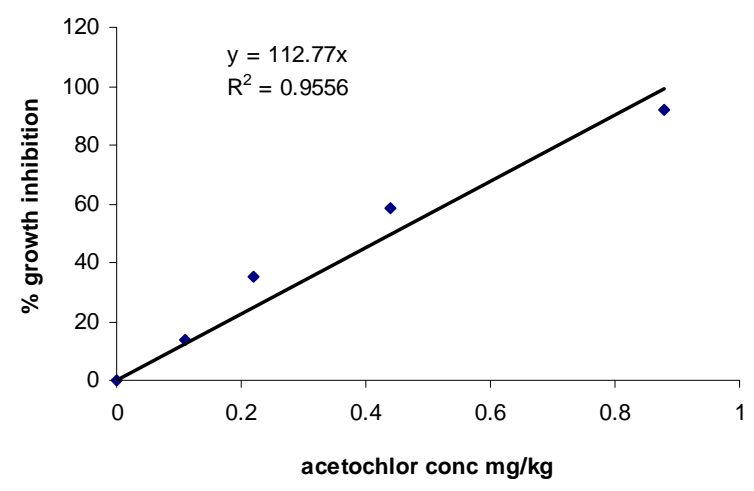

Figure 1. Dose response relationship of acetochlor concentration and wheat growth.
$0.88 \mathrm{mg} \cdot \mathrm{Kg}^{-1}$ soil) were applied to soil directly in the cultivation day. Each concentration has 5 replicates. The same concentrations were used in all the next experiments.

\subsubsection{Incubation of Acetochlor with Cyanobacterial Mats Directly in Pots for 20 Days}

In this experiment, soil samples ( $340 \mathrm{~g} /$ pot $)$ were sprayed with required acetochlor concentrations and cyanobacterial mat concentration $(20 \mathrm{ml} / \mathrm{pot})$ immediately in the same day and kept for incubation at saturation point for 2 weeks. The optical density of cyanobacterial mat concentration in the added solution to the pots or water systems was $0.214 \pm 0.001$. The concentration was determined using spectrophotometer at wave length $680 \mathrm{~nm}$ [23]. Then 10 seeds of the test plant were sown in each pot and the pots were transferred to the growth chamber for additional 2 weeks. The authors considered 10 seeds as significant for obtaining good quality statistical data. The pots were irrigated with $20 \mathrm{ml}$ water free from chlorine after germination of seeds. The authors used this small fraction of irrigation water to avoid possible leaching of acetochlor.

The plant was kept irrigated as required. The growth of the test plants were taken as indicator of the remaining concentration of acetochlor according to Equation (1).

\subsubsection{Effect of Different Factors on Acetochlor Biodegradation}

In this procedure we investigated the influence of three parameters as detailed in the sections below.

1) Influence of Incubating Acetochlor with Cyanobacterial Mats at a Liquid Media

To optimize the biodegradation of acetochlor the tested concentrations were separately incubated with cyanobacterial mat in a liquid media. In these experiments, the tested herbicide concentrations were prepared and transferred to glass bottles and $20 \mathrm{ml}$ of cyanobacterial mat was added to each bottle and completed to the required volume with tap water free from chlorine. The bottles were transferred to the growth chambers for 20 days. In this technique, the sterilized soil samples were transferred to plastic pots. Ten seeds of the test plant were sown in each pot. The pots were organized as groups according to the tested concentrations of each herbicide, then each group of pots was irrigated with $20 \mathrm{ml}$ of the tested concentration for one time only. The pots were then kept wet by the addition of few drops of irrigation. The pots were left in the growth chamber for 2 weeks and then the growth was calculated according to Equation (1).

Growth of the test plant was taken as indicator of the biodegradation of the herbicide.

Then the biodegradation experiments were tested by 
bioassay technique using Equation (1).

2) Influence of Different Incubation Period

In this procedure, the tested acetochlor concentrations were incubated with $20 \mathrm{ml}$ cyanobacterial mats in liquid media for 5, 10, 15, 25 and 30 days. Then the liquid media was used to irrigate pots pre-planted with 10 seeds of the test plant. The control sample of this experiment was incubating herbicides concentration in a liquid media without cyanobacterial mats for the same period of time.

Growth inhibition was taken as indicators of herbicides concentrations, and calculated according to Equation (1).

3) Influence of Various Cyanobacterial Mats Concentrations

Following the procedure described above, 10, 40, 50 and $80 \mathrm{ml}$ of cyanobacterial mats suspension were added to the tested concentration of herbicides for constant period. The liquid media used to irrigate pots pre-planted with 10 seeds of test plant.

Growth inhibition was taken as indicators of herbicides concentration, according to Equation (1).

\subsection{Chemo-Determination of Acetochlor}

Water samples were taken from the experiments mentioned above (Sections 2.6.3), and analyzed for possible residues of acetochlor following the procedure previously discibed [8]. In this procedure acetochlor was extracted from $10 \mathrm{ml}$ water sample by adding sodium chlo ride $(2.4 \mathrm{~g})$ into a glass tube, combined with $10 \mathrm{ml}$ of of ethyl acetate/isooctane $(1: 9 \mathrm{v} / \mathrm{v})$. The tubes were sealed, vortexed for $2 \mathrm{~min}$ at the highest speed, and stored at room temperature for 1 hour until the ethyl acetate/isooctane separated. The ethyl acetate/isooctane layer was collected into $25 \mathrm{ml}$ volumetric flasks. The extraction procedure was repeated twice. The extracts were brought to a volume of $25 \mathrm{ml}$ with the same solvent mixture, transferred to the crimp vials, sealed and analyzed at a reference laboratory at Cairo University, Egypt, using a Hewlett-Packard Model 6890 gas chromatograph, equiped with electron-capture detector. A Rtx ${ }^{\mathrm{R}}-5 \mathrm{MS}$ capillary column $(30 \mathrm{~m} \times 0.25 \mathrm{~mm}$ internal diameter, $0.25 \mu \mathrm{m}$ film) (Restek Corporation, Bellefonte, PA, USA) and nitrogen as the carrier gas at a flow-rate of $2 \mathrm{ml} \cdot \mathrm{min}^{-1}$. The nitrogen make-up flow-rate was $30 \mathrm{ml} \cdot \mathrm{min}^{-1}$. The injector and detector temperatures were $250^{\circ} \mathrm{C}$ and $280^{\circ} \mathrm{C}$, respectively, whereas the column was programmed at $170^{\circ} \mathrm{C}$ for $1 \mathrm{~min}$, then the temperature was increased at a rate of $5^{\circ} \mathrm{C} \mathrm{min}{ }^{-1}$ to $250^{\circ} \mathrm{C}$, and held at this temperature for $5 \mathrm{~min}$.

\subsection{Data Analysis}

The experiment design was a randomized block. The growth inhibition data were subjected to analysis of variance using repeated measures ANOVA. T-test was used to test the significant difference among treatments by calculating p-value at 0.05 levels. Values above 0.05 indicate no significant differences whereas values below 0.05 indicated significant differences. Average and standard deviation was calculated for each concentration.

\section{Results and Discussion}

The cyanobacterial mats used in this study was collected from Wadi Gaza. The Wadi receives a variety of pollution sources such as diesel oil, hydrocarbons, sewage, pesticides, solid waste as well as agricultural and Industrial discharges [17]. Fossil fuel pollution in Wadi Gaza, salinity, temperature and water level of the Wadi change seasonally, leading to marked changes in the appearance of the mats. In the western part, salinity ranges between $1 \%(\mathrm{w} / \mathrm{v}$ total salts) in winter and $3.5 \%$ in summer and the average daily temperature varies between $15^{\circ} \mathrm{C}$ in winter and $35^{\circ} \mathrm{C}$ in summer [16]. At the time of sampling, the mats were submerged, measured water temperature was $26^{\circ} \mathrm{C}$, and the salinity was $2 \%$. Microbial biofilms dominated by cyanobacteria were found to develop on the sediment surface in the presence of this high level of pollution. Abed et al. [16], studied the diversity of cyanobacteria at Wadi Gaza using direct microscopy as well as molecular approaches and showed that the Wadi was dominated by the diversity of cyanobacteria with phormidium and Oscillatoria-like morphotypes. Other bacterial populations belonging to Cytophaga Flavobater/Bacteroides group as well as $\beta$ and $\delta$ subclasses of the Proteobacteria were also detected. Phylogenetic analysis showed that some of these bacteria were related to environmental sequences retrieved from activated sludge, a finding consistent with the sewage pollution in the site, while others were related to the bacteria which is capable of degrading aromatic compounds.

\subsection{Soil Properties}

The physical analysis of the tested soil showed that sand, silt and clay contents were $92 \%, 2 \%$ and $6 \%$ respectively. The chemical analysis showed that $\mathrm{N} \%$ and $\mathrm{P} \%$ were 1.5 and 1.2 respectively, whereas $\mathrm{Na}^{+}, \mathrm{K}^{+}$and $\mathrm{Ca}^{++}$were $30.5,0.4$ and $29 \mathrm{mg} \cdot \mathrm{Kg}^{-1}$, respectively. $\mathrm{pH}$ and $\mathrm{EC}$ were 7.5 and 5.3 respectively.

\subsection{Bioremediation of Acetochlor}

\subsubsection{Dose-Response Relationship}

Responses of wheat plants to different concentrations of acetochlor are shown in Figure 1.

It can be seen that a linear relationship of low concentrations of acetochlor and wheat growth has been established $\left(\mathrm{R}^{2}=0.9556\right.$, and $\left.\mathrm{Y}=112.77 \mathrm{X}\right)$. This relationship allows us using the equation shown in Figure 1 to 
estimate the remaining concentration of acetochlor. This bioassay determination was previously reported [10].

An effect of acetochlor alone without incubation with cyanobacterial mat on wheat growth is shown in Figure 2. It can be seen that the acetochlor inhibits the growth of wheat as its concentration increased in the soil up to 0.88 $\mathrm{mg} \cdot \mathrm{Kg}^{-1}$. It is obvious that a leaner reduction in wheat growth is shown from the control samples $(0.0$ acetochlor) up to the highest concentration $0.88 \mathrm{mg} \cdot \mathrm{Kg}^{-1}$. Furthermore, the effect of acetochlor is more pronounced at higher concentrations than at lower ones.

Statistical analysis of the data in Figure 2 indicates significant differences among concentrations. We marked columns with the same letters wherever the differences are not significant at level of 0.05. The results in Figure 2 also indicate that acetochlor is stable in the soil environment.

\subsubsection{Bioremediation of Acetochlor in Soil Pots}

Effect of cyanobacterial mats on the degradation of acetochlor concentrations after 2 weeks period with incubation in soil are shown in Figure 3.

The presented results show similar wheat growth in the control samples and at the lowest concentration $\left(0.055 \mathrm{mg} \cdot \mathrm{Kg}^{-1}\right.$ soil $)$ tested. These results indicate that acetochlor disappeared from soil due to the possible degradation by cyanobacterial mats.

Growth reductions were obvious at high acetochlor concentrations (Figure 3). These results indicate that nearly moderate concentrations are still not degraded in the soil as shown by the growth reduction of wheat. Comparison between the growth in the control sample and the growth with the treatment that contains the lowest concentration indicate no difference. These results were also confirmed by the statistical analysis which shows no differences between the growths in the control samples and in $0.055 \mathrm{mg} \cdot \mathrm{Kg}^{-1}$ soil, indicating complete degradation of acetochlor. These data indicate possible mineralization of acetochlor at low concentration, which

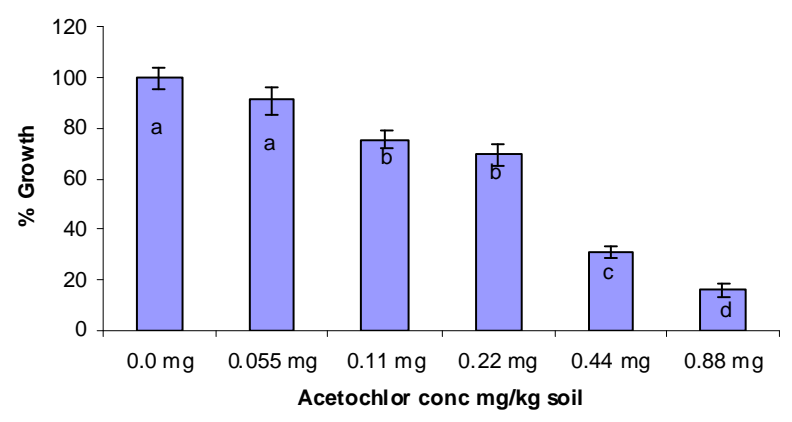

Figure 2. Effect of acetochlor concentration on wheat growth without incubation with cyanobacterial mats. Error bars represent standard deviation. Columns have the same letter are not significant different at $\alpha=0.05$.

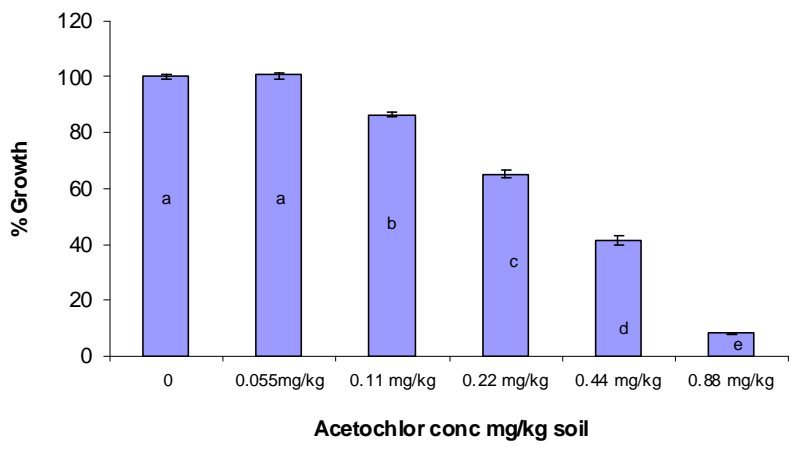

Figure 3. Effect of acetochlor concentration on wheat growth after 2 weeks incubation with cyanobacterial mats. Error bars represent standard deviation. Columns have the same letter are not significant different at $\alpha=0.05$.

agrees with Dictor et al. [26], who studied acetochlor mineralization and the fate of its two major metabolites in two soils under laboratory conditions.

Furthermore, at high concentrations the statistical analysis discriminate significant differences among the concentrations as shown by the letters presented on percent growth columns (Figure 3). In these cases, p-values were below 0.05 (data not shown).

In addition, the remaining concentrations of acetochlor were estimated according to the equation shown in Figure 1 and the data are presented in Table 1.

It can be seen that the treatments with cyanobacterial mats contain lower remaining concentration of acetochlor. Comparison between the initial concentration added and the remaining one indicates the activity of cyanobacterial mats as degraders to acetochlor.

It is obvious that there are decreases in all acetochlor concentrations in the presence of $\mathrm{CB}$. These results indicate that $\mathrm{CB}$ mat degraded acetochlor in a certain portion. These data are in accord with the data in Figure 1. Furthermore, the biodegradation of acetochlor is more pronounced at lower concentrations $(0.055,0.11,0.22$ $\mathrm{mg} \cdot \mathrm{Kg}^{-1}$ soil) than at higher concentrations $(0.44,0.88$ $\mathrm{mg} \cdot \mathrm{Kg}^{-1}$ soil). These results agree with $\mathrm{Xu}$ et al. [27], who tested the capability of 4 microbial communities for degrading acetochlor and found that acetochlor concentration of $55 \mathrm{mg} \cdot \mathrm{L}^{-1}$ was completely degraded by the four mixed cultures after 4 days. Furthermore, the remaining concentration of acetochlor (Table 1) revealed that the acetochlor degradation is not so fast in the soil media. This suggests that acetochlor or its metabolites in the soil may have a toxic effect on bacterial mats, this argument may stand behind the low degradation whenever acetochlor is incubated directly with cyanobacterial mats in the soil. Our suggestion is strongly supported by Virag et al. [28], who concluded that the acetochlor and its photolytic degradation products were found to be more toxic to the bacteria than the fungi. In addition, our results suggest that $\mathrm{CB}$ mats at high concretions of acetochlor may 
Table 1. Initial and estimated acetochlor concentrations after several periods of incubation with cyanobacterial mats in aquatic media.

\begin{tabular}{cccccc}
\hline \multirow{2}{*}{$\begin{array}{c}\text { Initial Conc. } \\
\mathrm{mg} / \mathrm{kg}\end{array}$} & $5 \mathrm{~d}$ & $10 \mathrm{~d}$ & $15 \mathrm{~d}$ & $20 \mathrm{~d}$ & $25 \mathrm{~d}$ \\
\cline { 2 - 6 } 0.055 & 0.03 & 0.02 & 0.02 & 0.02 & 0.01 \\
0.11 & 0.01 & 0.00 & 0.00 & 0.02 & 0.01 \\
0.22 & 0.02 & 0.01 & 0.02 & 0.02 & 0.01 \\
0.44 & 0.14 & 0.04 & 0.05 & 0.07 & 0.05 \\
0.88 & 0.40 & 0.07 & 0.07 & 0.07 & 0.02 \\
\hline
\end{tabular}

$\mathrm{d}=$ day.

undergo community changes that made them unable to make the required degradation at the same time. At low concentrations, the degradation was nearly at a high percentage indicating that no community changes would have occurred. Our suggestion agrees with Grötzschel et al. [29], who did not reveal any significant community changes at lower concentrations of petroleum products degraded by cyanobacterial mats. In contrast, $\mathrm{Wu}$ et al. [30], reported that acetochlor application changed the community structure of Pseudomonas in aquatic brown soil. The diversity of Pseudomonas and the amount of isolated Pseudomonas strains with antagonistic activity decreased with an increasing acetochlor concentration, and the toxic effect of acetochlor reached to a steady level at $150-250 \mathrm{mg} \cdot \mathrm{Kg}^{-1}$ soil. Influences of $\mathrm{CB}$ on degradation of acetochlor at saturated soil condition are shown in Figure 4. It is clear that there are nearly similar wheat growths in all concentration of acetochlor. Statistical analysis does not discriminate significant differences among acetochlor concentration regardless to the percent of wheat responses to the remaining concentrations of acetochlor.

However, the comparison between wheat growth percentage in the soil incubated with acetochlor and cyanobacterial mats together (Figure 3) and water saturated soil (Figure 4), indicates that at low acetochlor concentration, degradation was nearly similar and no significant differences were detected whereas at high acetochlor concentrations, degradation of acetochlor was more pronounced at water saturated soil incubated with acetochlor and cyanobacterial mats for 2 weeks (Figure 4). Statistical analysis indicates significant differences, $\mathrm{p}$-value $=$ 0.027 . The explanation of these results is that incubating the acetochlor, cyanobacterial mats and the soil in a saturated conditions, makes the media suitable for cyanobacterial mats growth. Accordingly, the Cyanobacterial mat grow rapidly and use acetochlor molecules as a source of energy. Similar explanation was given to the degradation of phenanthrene by cyanobacterial mats [19].
Furthermore, the incubation cyanobacterial mat with soil for 2 weeks at normal soil conditions may not be enough time to allow the cyanobacterial mats to grow as rapid as necessary to degrade acetochlor.

\subsection{Effect of Different Factors in Biodegradation}

\subsubsection{Liquid Media Studies}

In these experiments, acetochlor was incubated in a liquid media with cyanobacterial mats for various periods of time. Then the liquid media were evaluated by bioassay to determine the residues of acetochlor in the solution. Results of these experiments are shown in Figure 5.

It can be seen that incubating acetochlor in the liquid media without cyanobacterial mats (Figure 5) did not show any degradation and the acetochlor remains active as a herbicide as shown by wheat growth percentage decline as the acetochlor concentration increased in the liquid media. These results indicate that the acetochlor persists water hydrolysis. Similar result was shown by El-Nahhal [10], who showed persistence of chloroacetanilide herbicides under field conditions. In the way

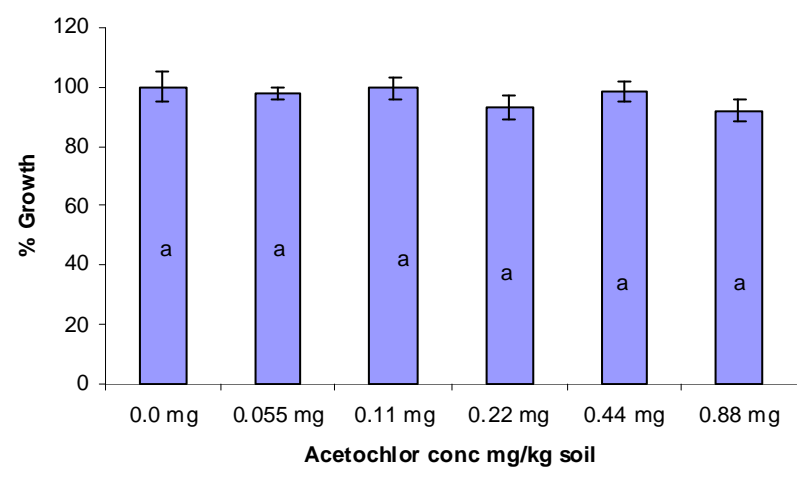

Figure 4. Effect of acetochlor concentrations on wheat growth with incubation with cyanobacterial mats in water saturated soil for 2 weeks. Error bars represent standard deviation. Columns have the same letter are not significant different at $\alpha=0.05$.

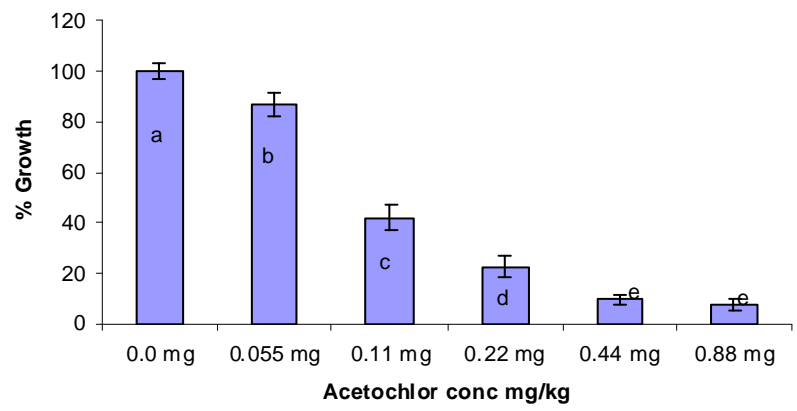

Figure 5. Effect of acetochlor concentration on wheat growth without incubation of cyanobacterial mats in a liquid media. Error bars represent standard deviation. Columns have the same letter are not significant different at $\alpha=$ 0.05 . 
around, the acetochlor nearly degraded completely (Figure 6) when it was incubated with cyanobacterial mat in a liquid media. These results are in accord with the above mentioned results. Furthermore, wheat plant nearly grew normally in pots irrigated with acetochlor concentrations incubated with cyanobacterial mats for 20 days, whereas the growth was severely reduced in the liquid media containing acetochlor without cyanobacterial (Figure 5). Statistical analysis between the 2 treatments indicates significant difference, $\mathrm{p}$-value $=0.0047$.

Estimation of the remaining concentration of acetochlor (Table 1) indicated that large fraction of acetochlor was disappeared due to the possible degradation by cyanobacterial mats. It is also obvious that the remaining concentration is nearly evenly degraded by cyanobacterial mats.

\subsubsection{Degradation of High Concentrations of Acetochlor}

Degradation of high concentrations of acetochlor is shown in Figure 7. It can be seen that the wheat grew normally in pots irrigated with high concentration of acetochlor incubated with cyanobacterial mat in the liquid media. These results indicate that the cyanobacterial mats were able to degrade wide range of acetochlor concentrations (1 - 3 folds of field rates). Our results agree with recent report [31], which indicates that microorganisms, comprising two main branches of the tree of life, have acquired the ability to degrade the same novel chlorinated herbicide that has been recently added to the biosphere. Furthermore, early reports [16-19], indicated that the cyanobacterial mats were able to degrade high concentration of petroleum products.

Statistical analysis showed significant difference at the highest concentrations as shown by the different letters in the columns of Figure 7.

Furthermore, the statistical analysis at the highest concentrations $\left(1.76-2.2 \mathrm{mg} \cdot \mathrm{Kg}^{-1}\right.$ soil) did not dis-

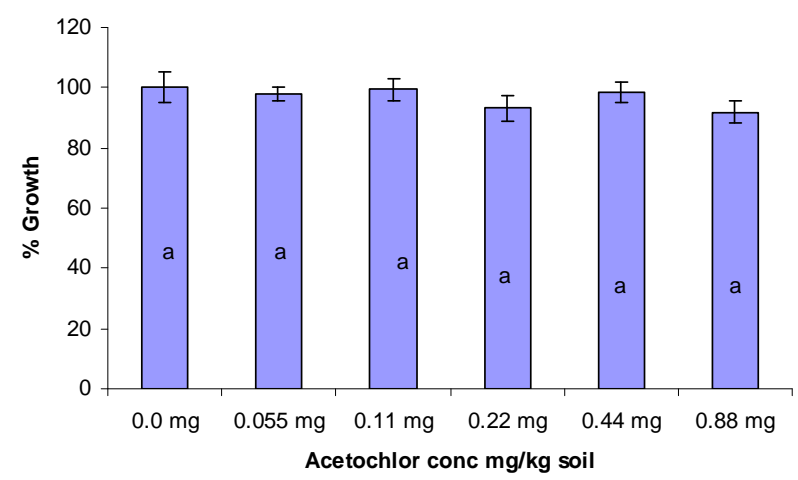

Figure 6. Effect of acetochlor concentration on wheat growth with incubation of cyanobacterial mats in a liquid media. Error bars represent standard deviation. Columns have the same letter are not significant different at $\alpha=0.05$.

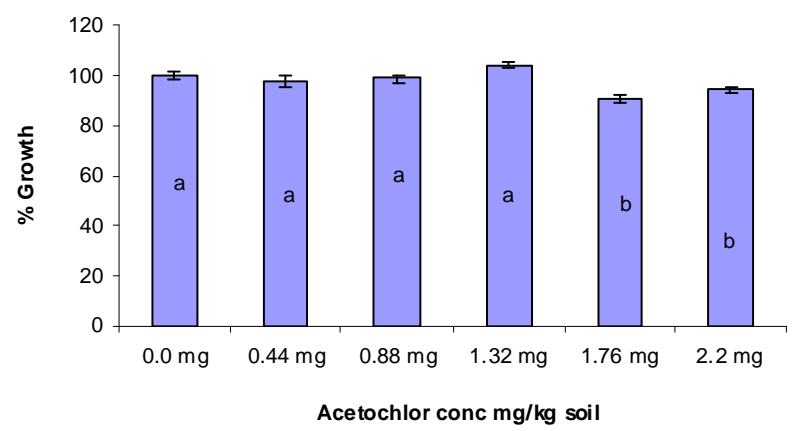

Figure 7. Influence of cyanobacterial mats on degradation of high concentration of acetochlor in aquatic media $(1,2,3,4$, and 5 folds of field rate). Effect measured as growth inhibition on wheat as test plant 20 days of incubation. Error bars represent standard deviation. Columns have the same letter are not significant different at $\alpha=0.05$.

criminate differences. This indicates that the degradation of acetochlor at high concentrations is nearly similar. This may be explained by the fact that at high concentrations, some community changes may occur and the degradation may be affected. Similar explanation was given above for other cases.

Furthermore, the remaining concentrations were estimated and presented in Table 1, and it was realized that large fraction disappeared, due to the possible degradation. It is obvious that there is a good agreement between the data in Table 1.

\subsubsection{Kinetics of Acetochlor Degradation}

Kinetic degradation of acetochlor concentrations after different periods of time $(5,10,15$, and 25 days) are shown in the Figures 8 and $\mathbf{9}$.

It is obvious that acetochlor concentrations below 0.22 $\mathrm{mg} \cdot \mathrm{Kg}^{-1}$ soil were nearly completely degraded by cyanobacterial mats after 5 days of incubating acetochlor with cyanobacterial mats at room temperature in a liquid media. The statistical analysis did not discriminate significant difference indicating the absence of acetochlor from the liquid media. However, comparison between the growth in control samples $\left(0.0 \mathrm{mg} \cdot \mathrm{Kg}^{-1}\right.$ soil $)$ and those of high concentrations $\left(0.44,0.88 \mathrm{mg} \cdot \mathrm{Kg}^{-1}\right.$ soil) show different growths of wheat. Statistical analysis show significant difference, $\mathrm{p}$-value $=3.7 \mathrm{E}-6$.

The data in Figure 8, clearly demonstrate that the degradation of acetochlor concentrations is completely achieved after 10 days as shown by the growth percent of wheat, and this is similar to the degradation after 15 and 25 days (Figure 9). Comparison of the degradation after 10, 15 and 25 days clearly showed no significant difference as shown by the letters in the columns of Figure 8 and they are all the same.

Furthermore, the estimation of the remaining concentrations after 10 - 25 days (Table 1) showed nearly 


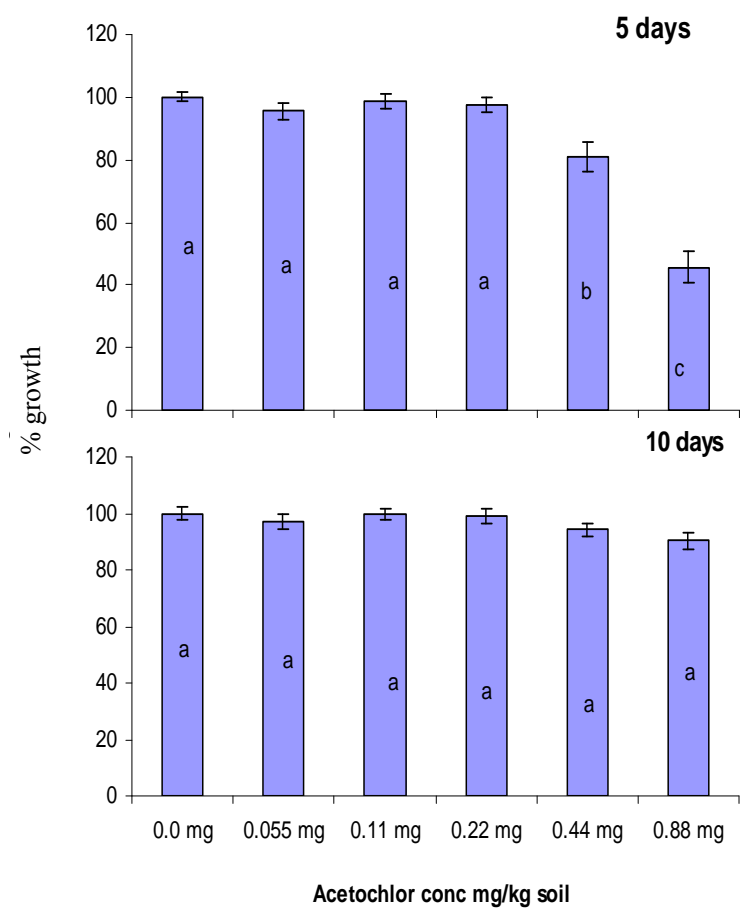

Figure 8. Degradation of acetochlor after 5, and 10 days after incubation with cyanobacterial mats in liquid media. Effect measured as growth inhibition in wheat as test plants. Error bars represent standard deviation. Columns have the same letter are not significantly different at $\alpha=0.05$.

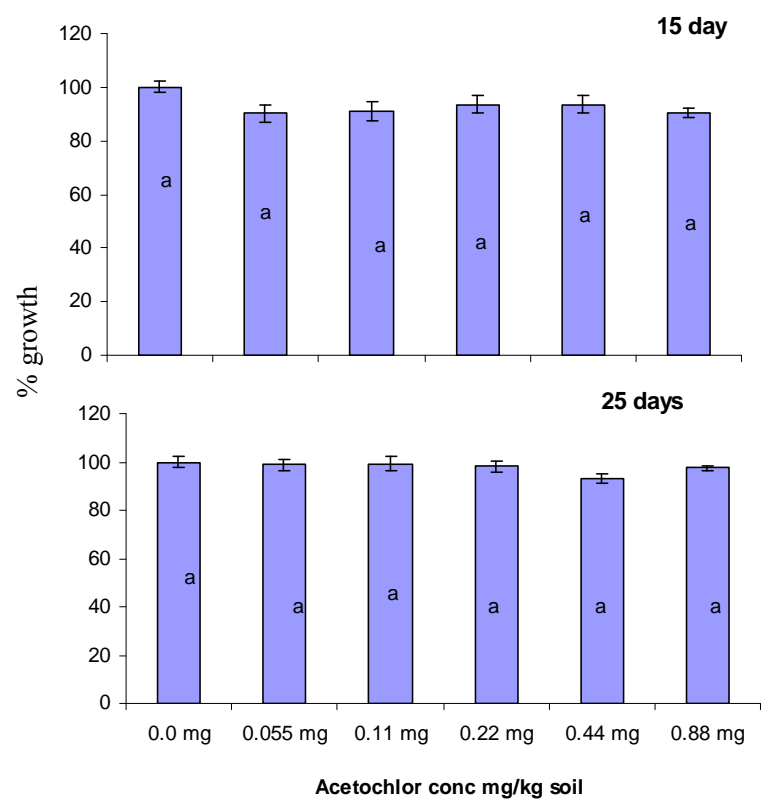

Figure 9. Degradation of acetochlor after 15 and 25 days after incubation with cyanobacterial mats in liquid media. Effect measured as growth inhibition in wheat as test plants. Error bars represent standard deviation. Columns have the same letter are not significantly different at $\alpha=0.05$.

closed growth response, indicating similar degradation. Regardless to the data in Figure 8, it can not be con- cluded that the acetochlor degraded completely after 10 day. It can be suggested that some residues still exist in the soil as acetochlor and it is below the phyto-toxicity levels of wheat.

However, our result agree with Zhang et al. [32], who showed that acetochlor had an acute toxic effect on the growth of bacteria in agricultural black soil. Furthermore, it can be suggested that acetochlor is rapidly metabolized to a non-toxic fragment to the wheat plant as it is exposed to cyanobacterial mats in the liquid media. This suggestion is in agreement with Zhang et al. [33], who isolated a non-toxic metabolite of acetochlor to bacteria.

\subsubsection{Effect of Bacterial Concentrations on Acetochlor Degradation}

Effect of various concentrations of cyanobacterial mat suspension on the degradation of acetochlor concentration is shown in Figure 10. It is obvious that acetochlor concentration which was not incubated with cyanobacterial mat suspension $(0.44+0 \mathrm{ml})$ showed complete growth reduction of wheat (Figure 10), whereas, acetochlor concentration incubated with various concentration of cyanobacterial mat suspension below $(0.44+50$ $\mathrm{ml}$ ) showed nearly similar wheat growth but the growth of wheat in the control sample was a bit higher than those with the treatments. This indicates that the degradation was not completed after incubation with cyanobacterial mat suspension equal to or below $50 \mathrm{ml} /$ pot.

Furthermore, the incubation of acetochlor with cyanobacterial mats in amounts above $50 \mathrm{ml}$ (Figure 10) per pot showed nearly complete degradation of acetochlor as shown by the growth of wheat. Statistical analysis of the date in Figure 10 showed significant difference among the treatments as shown by the letters in each column. Above $50 \mathrm{ml}$ cyanobacterial mat suspension, the statistical analysis showed no significant difference among the treatment that contains cyanobacterial mats and signifi-

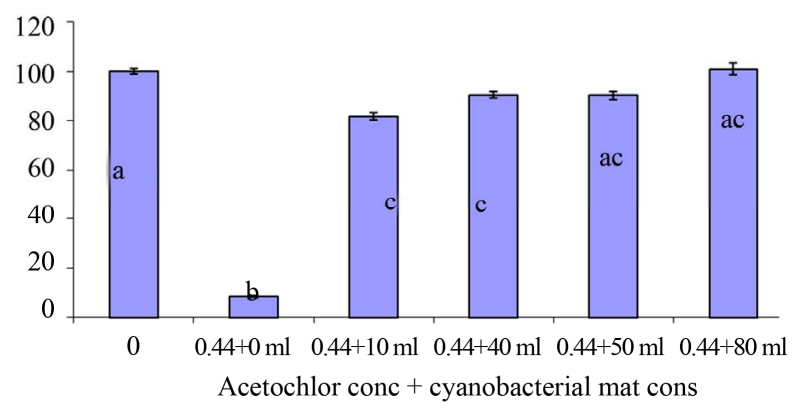

Figure 10. Effect of various concentrations of cyanobacterial mat on biodegradation of fixed acetochlor concentration. (0.44 $\mathrm{mg} / \mathrm{kg}$ soil) after 20 days of incubation in aquatic media. Effect measured as growth inhibition in wheat as test plants. Error bars represent standard deviation. Columns have the same letter are not significantly different at $\alpha=0.05$. 
cant difference with that does not contain cyanobacterial mat as shown by the letter in the column. These results clearly suggest that the concentration of cyanobacterial mat suspension has a great role in the degradation of acetochlor. Estimated remaining concentrations are shown in Table 1.

It can be seen that the remaining concentrations of the acetochlor treatment with cyanobacteria is a function of the concentration of cyanobacterial mats.

Treatments, that have $50 \mathrm{ml}$, have nearly little remaining concentrations whereas without treatments, that have $40 \mathrm{ml}$, contain high remaining concentration. This suggested that the bacterial concentration have significant role in the biodegradation process.

However, the limitation of this study is that the active cyanobacterial mats that degraded acetochlor may not be abundant and available in the Wadi Gaza during the season of the year. In addition, organic pollutants are usually found as mixtures in the Wadi Gaza, this mixture may have a toxic effect on the cyanobacterial mats accordingly biodegrading is delayed or not happen.

\subsection{Chemo-Determination of Acetochlor}

Blank recovery of acetochlor from water samples was $87 \% \pm 7 \%$ indicating good extraction procedure. Furthermore, GC analytical results of acetochlor are presented in Table 2. It can be seen that at low added acetochlor concentration the extracted amounts are below the detection limits of the GC. At high added concentration of acetochlor, the extracted amounts ranged between $0.15-0.45,0.15-0.3,0.2$ and $0.0 \mathrm{mg} \cdot \mathrm{Kg}^{-1}$ soil after 5, 10,15 and 25 days of biodegradation respectively. These results confirmed that acetochlor was degraded by cyanobacterial mats. Comparison between these data and the data in Table 1 (estimating acetochlor by bioassay technique) indicates that bioassay technique is more sensitive and more accurate in determining low concentrations of acetochlor whereas GC-determination was not able to detect concentrations below detection limit of GC. Furthermore, at high applied acetochlor concentration,

Table 2. GC-determination of acetochlor concentrations in selected water samples.

\begin{tabular}{ccccc}
\hline & \multicolumn{4}{c}{ Determined concentration mg/kg } \\
\cline { 2 - 5 } $\mathrm{C}_{\mathrm{i}}$ & $5 \mathrm{~d}$ & $10 \mathrm{~d}$ & $15 \mathrm{~d}$ & $25 \mathrm{~d}$ \\
\hline 0.055 & $\mathrm{Bd}$ & $\mathrm{Bd}$ & $\mathrm{Bd}$ & $\mathrm{Bd}$ \\
0.11 & $\mathrm{Bd}$ & $\mathrm{Bd}$ & $\mathrm{Bd}$ & $\mathrm{Bd}$ \\
0.22 & $\mathrm{Bd}$ & $\mathrm{Bd}$ & $\mathrm{Bd}$ & $\mathrm{Bd}$ \\
0.44 & 0.15 & 0.15 & $\mathrm{Bd}$ & $\mathrm{Bd}$ \\
0.88 & 0.4 & 0.3 & 0.2 & $\mathrm{Bd}$ \\
\hline
\end{tabular}

$\mathrm{C}_{\mathrm{i}}=$ Initial conc. $\mathrm{mg} / \mathrm{kg}$; $\mathrm{d}=$ day.
GC determined concentrations of acetochlor higher than bioassay technique. These results agree with El-Nahhal [24], who obtained similar results with metolachlor.

\section{Conclusions}

Degradation method includes:

1) Collecting cyanobacterial mats from Wadi Gaza and incubating them with soil at a saturation level and/or in a liquid media for adaptation;

2) Incubation of cyanobacterial mats with acetochlor concentrations in a liquid media at lab conditions;

3) Bioassay and chemoassay techniques were used to test the degradation process.

Biodegradation of acetochlor was successfully performed by cyanobacterial mats at low concentrations in the soil and liquid media. Bio-degradation of acetochlor was more pronounced in the liquid media than in the soil. Kinetic studies indicated that acetochlor degraded fully after 25 days in the liquid media.

Cyanobacterial mats were able to degrade concentrations of acetochlor several times higher than the applied field rate. The application of high concentration of cyanobacterial mat may further enhance the degradation process. The bioassay estimation of acetochlor concentration was more sensitive and accurate than GC determination at low concentrations whereas GC determined more acetochlor concentration than bioassay did at high applied rate.

These remarks suggest that acetochlor can easily be degraded by cyanobacterial mats.

It can be concluded that the various concentrations of acetochlor contained in the soil could be degraded by cyanobacterial mats within a 30 days.

It is encouraging results that cyanobacterial mats can be used for bioremediation of soil and/or water pollution.

\section{Acknowledgements}

Dr Y. El-Nahhal acknowledges Alexander von Humboldt Stiftung/Foundation Fellowship Grant no IV-PAL/1104842 STP, Germany.

\section{REFERENCES}

[1] O. Andrén and J. Lagerlöf, "Soil Fauna Microarthropods. Enchytraeids, Nematodes in Swedish Agricultural Cropping Systems," Acta Agriculture Scandinavian, Vol. 33, No. 1, 1983, pp. 33-52. doi:10.1080/00015128309435350

[2] D. J. Ecobichon, J. E. Davies, J. Doull, M. Ehrich, R. Joy, D. McMillan, R. MacPhail, L. W. Reiter, W. Slikker and H. Tilson, "Neurotoxic Effects of Pesticides," In: C. F. Wilkinson and S. R. Baker, Eds., The Effect of Pesticides on Human Health, Princeton Scientific Publisher, Princeton, 1990, pp. 131-199.

[3] D. Pimentel, "Ecological Effects of Pesticides on Non- 
Target Species in Terrestrial Ecosystems," In: R. G. Tardiff, Ed., SCOPE 49: Methods to Assess Adverse Effects of Pesticides on Non-Target Organisms, John Wiley \& Sons, Toronto, 1992, pp. 171-190.

[4] Environmental Protection Agency, "Questions and Answers, Conditional Registration of Acetochlor," US Environmental Protection Agency, Washington DC, 1994.

[5] D. W. Kolpin, B. K. Nations, D. A. Goolsby and E. M. Thurman, "Acetochlor in the Hydrologic System in the Midwestern United States," Environmental Science and Technology, Vol. 30, No. 5, 1996, pp. 1459-1464. doi:10.1021/es9503241

[6] A. William, D. Battaglin, W. Kolpin, A. Elizabeth, K. Scribner, M. Kuivila and W. Mark, "Glyphosate, Other Herbicides, and Transformation Products in Midwestern Streams, 20021," Journal of American Water Research Association, Vol. 41, No. 2, 2005, pp. 323-329. doi:10.1111/j.1752-1688.2005.tb03738.x

[7] J. Gilliom, E. Barbash, G. Crawford, A. Hamilton, D. Martin, N. Nakagaki, H. Nowell, C. Scott, E. Stackelberg, P. Thelin and M. Wolock, "Pesticides in the Nation's Streams and Ground Water, 1992-2001," The Quality of Our Nation's Waters, Series Number 1291, USGS, 2006.

[8] Y. El-Nahhal, S. Nir, S. Serban, O. Rabinowitz and B. Rubin, "Organoclay Formulation of Acetochlor for Reduced Movement in Soil," Journal of Agricultural and Food Chemistry, Vol. 49, No. 11, 2001, pp. 5464-5371. doi:10.1021/jf010561p

[9] M. Balinova, "Acetochlor-a Comparative Study on Parameters Governing the Potential for Water Pollution," Journal of Environmental Science and Health, Part B, Vol. 32, No. 5, 1997, pp. 645-658.

[10] Y. El-Nahhal, "Persistence, Mobility, Efficacy and Safety of Chloroacetanilide Herbicide Formulation under Field Conditions," Environmental Pollution, Vol. 124, No. 1, 2003, pp. 33-38. doi:10.1016/S0269-7491(02)00431-1

[11] L. N. Konda and Z. S. Pasztor, "Environmental Distribution of Acetochlor, Atrazine, Chlorpyrifos and Propisochlor under Field Conditions," Journal of Agricultural and Food Chemistry, Vol. 49, No. 8, 2001, pp. 3859-3863. doi:10.1021/jf010187t

[12] P. M. Hurley, R. N. Hill and R. J. Whiting, "Mode of Carcinogenic Action of Pesticides Inducing Thyroid Follicular Cell Tumors in Rodents," Environmental Health Perspective, Vol. 106, No. 8, 1998, pp. 437-446. doi:10.1289/ehp.98106437

[13] P. J. Deirickx, "Glutathione-Dependent Cytotoxicity of The Chloroacetanilide Herbicides Alachlor, Metolachlor, and Propachlor in Rat and Human Hepatoma-Derived Cultured Cells," Cell Biology and Toxicology, Vol. 15, No. 5, 1999, pp. 325-332. doi:10.1023/A:1007619919336

[14] K. L. Dearfield, N. E. Mc Carroll, A. Protzel, H. F. Stack, M. A. Jackson and M. D. Waters, "A Survey of EPA/OPP and Open Literature on Selected Pesticide Chemicals II. Mutagenicity and Carcinogenicity of Selected Chloroacetanilides and Related Compounds," Mutation Research, Vol. 443, No. 1-2, 1999, pp. 183-221. doi:10.1016/S1383-5742(99)00019-8

[15] United States Environment Protection Agency, “Ace- tochlor: Fifth Report of the Cancer Assessment Review Committee," OPP Official Record, Health Effect Division, Scientific Data Reviews, EPA, Washington DC, 2007.

[16] R. M. M. Abed, N. M. D. Safi, J. Koster, D. de Beer, Y. El-Nahhal, J. Rullkotter and F. Garcia-Pichel, "Microbial Diversity of a Heavily Polluted Microbial Mat and Its Community Changes Following Degradation of Petroleum Compounds," Applied Environmental Microbiology, Vol. 68, No. 4, 2002, pp. 1674-1683. doi:10.1128/AEM.68.4.1674-1683.2002

[17] N. Safi, J. Koster and J. Rulkotter, "Fossil Fuel Pollution in Wadi Gaza and Biodegradation of Petroleum Model Compounds by Cyanobacterial Mats," The 36th Congress of the International Commission for the Scientific Exploration of the Mediterranean Sea, Monaco, 2001, p. 209.

[18] N. Safi, N. Lee, J. Koster, J. Safi, Y. El-Nahhal, M. Wagner and J. Rullkotter, "Biodegradation of Petroleum Modle Compounds by in Mesocosm Experiments in Gaza (Palestine)," 21 st International Meeting on Organic Geochemistry, Krakow, 8-12 September 2003, pp. 138-139.

[19] N. Safi, "Environment Organic Geochemistry of Sediments from Wadi Gaza and Investigation of Bioremediation of Petroleum Derivatives and Herbicides by Cyanobacterial Mats under Different Experimental Conditions," Ph.D. Thesis, Carl von Ossietzky Universitat, Oldenburg, 2004

[20] C. D. Tomlin, "The Pesticide Manual," British Crop Protection Council, Farnham, 2000.

[21] Y. El-Nahhal, S. Nir, T. Polubesova and L. Margulies, "Rubin B. Leaching, Phytotoxicity and Weed Control of New Formulations of Alachlor," Journal of Agricultural and Food Chemistry, Vol. 46, No. 8, 1998, pp. 3305-3313. doi:10.1021/jf971062k

[22] W. H. Paerl, F. T. Steppe, C. K. Buchan and M. Potts, "Hypersaline Cyanobacterial Mats as Indicators of Elevated Tropical Hurricane Activity and Associated Climate Change,' Ambio, Vol. 32, No. 2, 2003, pp. 87-90.

[23] J. Ma, R. Zheng, L. Xu and S. Wang, "Differential SensiTivity of Two Green Alga Scenedesmus obliqnus and Chlorella pyrenoidosa to 12 Pesticides," Ecotoxicology and Environmental Safety, Vol. 52, No. 1, 2002, pp. 5761. doi:10.1006/eesa.2002.2146

[24] Y. El-Nahhal, "Leaching Behavior of Metolachlor in Soil," Journal of Environmental Engineering and Science, Vol. 3, No. 3, 2004, pp. 187-194. doi:10.1139/s03-075

[25] Y. El-Nahhal, G. Lagaly and O. Rabinovitz, "OrganoClay Formulations of Acetochlor: Effect of High Salt," Journal of Agricultural and Food Chemistry, Vol. 53, No. 5, 2005, pp. 1620-1624. doi:10.1021/jf040383a

[26] M. Dictor, N. Baran, A. Gautier and C. Mouvet, "Acetochlor Mineralization and Fate of Its Two Major Metabolites in Two Soils under Laboratory Conditions," Chemosphere, Vol. 71, No. 4, 2008, pp. 663-670. doi:10.1016/i.chemosphere.2007.10.066

[27] J. Xu, M. Yang, J. Dai, H. Cao, C. Pan, X. Qiu and M. Xu, "Degradation of Acetochlor by Four Microbial Communities," Bio-Resource Technology, Vol. 99, No. 16, 2008, pp. 7797-7802. doi:10.1016/j.biortech.2008.01.060 
[28] D. Virág, Z. Naár and A. Kiss, "Microbial Toxicity of Pesticide Derivatives Produced with UV-Photodegradation," Bulletin of Environmental Contamination and Toxicology, Vol. 79, No. 3, 2007, pp. 356-359. doi:10.1007/s00128-007-9230-7

[29] S. Grotzschel, J. Koster, R. M. Abed and D. de Beer, "Degradation of Petroleum Model Compounds Immobilized on Clay by a Hypersaline Microbial Mat," Biodegradation, Vol. 13, No. 4, 2002, pp. 273-283. doi:10.1023/A:1021263009377

[30] M. Wu, X. Zhang, H. Zhang, Y. Zhang, X. Li, Q. Zhou and C. Zhang, "Soil Pseudomonas Community Structure and Its Antagonism towards Rhizoctonia solani under the Stress of Acetochlor," Bulletin of Environmental Contamination and Toxicology, Vol. 83, No. 3, 2009, pp. 313317.
[31] A. Munoz, W. C. Koskinen, L. Cox and M. J. Sadowsky, "Biodegradation and Mineralization of Metolachlor and Alachlor by Candida xestobii," Journal of Agricultural and Food Chemistry, Vol. 59, No. 2, 2011, pp. 619-627. doi:10.1021/jf103508w

[32] H. W. Zhang, Q. X. Zhou, Q. R. Zhang and C. G. Zhang, "Soil Pseudomonas Community Structure and Its Antagonism towards Rhizoctonia solani under the Stress of Acetochlor," Bulletin of Environmental Contamination and Toxicology, Vol. 83, No. 3, 2009, pp. 313-317. doi:10.1007/s00128-009-9731-7

[33] J. Zhang, J. W. Zheng, B. Liang, C. H. Wang, S. Cai, Y. Y. Ni, J. He and S. P. Li, "Biodegradation of ChloroAcetamide Herbicides by Paracoccus sp. FLY-8 in Vitro," Journal of Agricultural and Food Chemistry, Vol. 59, No. 9, 2011, pp. 4614-4621. doi:10.1021/jf104695g 